\title{
FIRST RECORD OF Azygia robusta (Odhner, 1911) (Trematoda: Digenea: Azygiidae) IN BROWN TROUT (Salmo trutta) IN THE VRBAS RIVER
}

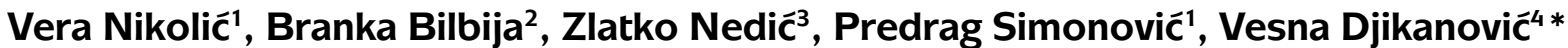

${ }^{1}$ Institute of Zoology, University of Belgrade Faculty of Biology, Studentski trg 16, 11001 Belgrade, Serbia

${ }^{2}$ University of Banja Luka, Faculty of Science, Mladena Stojanovica 2, 78000 Banja Luka, Bosnia and Herzegovina

${ }^{3}$ Department of Biology, University of Tuzla, Faculty of Science, Studentska 4, 75000 Tuzla, Bosnia and Herzegovina, Secondary high School of Orašje, 11 Ulica, 76270, Orašje, Bosnia and Herzegovina

${ }^{4}$ Institute of Biological Research "Siniša Stankovič", University of Belgrade, Despot Stefan Blvd 142, 11060

Belgrade, Serbia

* Corresponding author, Email: djiki@ibiss.bg.ac.rs

\section{ARTICLE INFO}

Received: 3 October 2017

Received in revised form: 29 March 2018

Accepted: 3 April 2018

Available online: 13 May 2018

\begin{abstract}
The investigation of fish parasites in Bosnia and Herzegovina in recent years became significant, and therefore new records of parasitic trematodes and their hosts are important for better understanding of fish parasitology and pathology. In this study 41 parasitic specimens were collected and the basic taxonomical characters were measured (body length and width, diameter of oral and ventral sucker, length and width of pharynx, ovary length and width, testes length and width and eggs length and width). After the sampling of the parasites, they were collected and conserved in $70 \%$ ethanol. After that procedure the aforementioned characters were measured using Digimizer Image Analyzer Version 4.1. After all measurements, the trematode parasite Azygia robusta was confirmed for the first time on brown trout Salmo trutta. This first record was found in the Vrbas River near Banja Luka, Bosnia and Herzegovina (Sava River Basin). Former records of this parasite in Europe were observed on other salmonid fish species, as huchen Hucho hucho. This new record should be very important part of data of fish parasitology in Bosnia and Herzegovina.
\end{abstract}

\author{
Keywords: \\ Parasites \\ Bosnia and Herzegovina \\ Trematodes \\ New record
}

Nikolić, V., Bilbija, B., Nedić, Z., Simonović, P., Djikanović, V. (2018): First record of Azygia robusta (Odhner, 1911) (Trematoda: Digenea: Azygiidae) in brown trout (Salmo trutta) in the Vrbas River Croatian Journal of Fisheries, 76, 85-88. DOI: $10.2478 /$ cjf-2018-0011.

\section{INTRODUCTION}

The species of genus Azygia (Trematoda: Digenea) are intestinal parasites of freshwater fishes (Bauer, 1987; Moravec, 2004) and some authors argue that biological cycle of this parasite is unknown (Čanković et al., 1968; Moravec, 2004). In Europe, A. robusta was recorded only in Austria, Russia and Bosnia and Herzegovina in huchen (Hucho hucho) (Čanković et al., 1968) and Siberian salmon 
(Hucho taimen) (Andrić, 1984; Holčik et al., 1998; Pulgachev, 2003; Moravec, 2004; Popiolek et al., 2013). According to European studies and published checklists, ordinary hosts for the species A. robusta are pike (Esox lucius), burbot (Lota lota), and the most dominant host is the huchen (Hucho hucho) (Bykhovskaja-Pavlovskaja et al., 1962; Andrić, 1984; Moravec, 2004; Simonović et al. 2011; Djikanovic et al. 2012). This trematode species has never been reported as a parasite in brown trout, neither in Europe or Asia until now (Čanković et al., 1968; Moravec, 2004).

All present findings of species $A$. robusta were published in a number of investigations in Asia (rivers in Siberia, Baikal Lake, and Amur River) (Bykhovskaja-Pavlovskajaet et al., 1962) while in Europe these findings are random and single. This intestinal trematod species is distributed in Palearctic area hosted mainly on huchen Hucho hucho (Salmonidae) (Bykhovskaja-Pavlovskaja et al., 1962; Čanković et al., 1968; Bauer, 1987; Holčik et al., 1998; Moravec, 2004). This new record presents important data about parasitology and life cycle of $A$. robusta which should be used as a pattern for new investigation of similar or same parasites.

\section{MATERIALS AND METHODS}

The Vrbas River is a major river in western Bosnia and Herzegovina, with length of $235 \mathrm{~km}$. It is a right tributary of the Sava River. From one locality of that river ( $N 44^{\circ}$ $45,914^{\prime}, \mathrm{E} 017^{\circ} 11,326^{\prime}$ ) one species of brown trout (length $43 \mathrm{~cm}$, weight $1.247 \mathrm{~g}$ ) was sampled with the help of local commercial fisherman using living worm as bait. Brown trout has been cut open and examined. During the examination of the body cavity using binocular microscope Zeiss (magnification $0.63-6.3 \mathrm{x}$ ) helminth parasites $A$. robusta are found in the muscles and intestine. A total of 41 specimens of $A$. robusta were identified. Parasites were fixed in $70 \%$ ethanol and cleared in 70\% lactophenol. Photomicrographs were taken using a Leica EZ4D (magnification 16x) and body measures were taken by Digimizer Image Analyzer Version 4.1.The basic taxonomical characters were compared using the identification keys for taxonomical determination (Moravec, 2004; Čanković at al., 1968).

\section{RESULTS AND DISCUSSION}

Trematoda parasites taken from the brown trout were hitelike to yellowish-pink in color. Adult worms were narrowly attached to the folds of intestine epithelia by their muscular sucker, or they were attached to the muscles. Freshly removed worms were reddish or pale, broad at the middle and narrowly rounded at both ends. Twelve taxonomic body characters were measured (Table 1). After measuring, the study showed several important parameters indicating Azygia robusta (Odhner, 1911) species (Fig. 1).

Taxonomic characters of two species of Azygia genus ( $A$. lucii and $A$. robusta) have been compared because of their similarity. All parasites were in range of $18.50-32.50 \mathrm{~mm}$ long, thus matching the length of $A$. robusta (Čanković et al. 1968; Moravec, 2004) (Table 1). A similar species, Azygia lucii, is smaller, with length in the range of $8-40 \mathrm{~mm}$ (Čanković et al., 1968; Bauer, 1987). Body width of $A$. robusta was earlier described in the range of $0.5-5.0 \mathrm{~mm}$ range, and this study showed that all the located individuals were indeed in that range of body width (Bauer, 1987; Moravec, 2004). In accordance with this fact, the study showed that sampled parasitic individuals were smaller (Table 1). The diameter of oral sucker is bigger than the diameter of its ventral sucker (Čanković et al., 1968; Bauer, 1987; Moravec, 2004) (Table 1).

The two most important parameters that made the difference between two similar species from the genus Azygia were width and length of pharynx. According to earlier studies, pharynx of $A$. robusta is spherical (Table 1 , Fig. 1), and it is almost impossible to see any difference between length and width of pharynx. A. lucii, has a long pharynx with visible difference in length and width (Čanković et al. 1968; Kakačeva-Avramova, 1983; Bauer, 1987; Moravec, 2004). The dimension of ovaries, testes and eggs of measured individuals undoubtedly indicates on A. robusta (Bauer, 1987). After 45 years, this parasite has been found in the intestines of the brown trout specimen in Vrbas River. This first record of $A$. robusta in brown trout Salmo trutta, as a new fish host for it, is significant for distribution of this trematoda. New host of $A$. robusta

Table 1. Measured body characters of Azygia robusta (mm)

\begin{tabular}{|c|c|c|c|c|c|c|c|c|c|c|c|c|c|c|}
\hline & $B L$ & BW & OSD & VSD & PW & PL & OL & ow & TL 1. & TW 1. & TL 2. & TW 2. & EL & EW \\
\hline AV & 24,43 & 1,57 & 1,31 & 1,09 & 0,55 & 0,59 & 0,83 & 0,78 & 0,94 & 0,88 & 1,05 & 0,92 & 0,0445 & 0,0296 \\
\hline MIN & 18,50 & 1,22 & 1,04 & 0,81 & 0,44 & 0,48 & 0,53 & 0,59 & 0,73 & 0,68 & 0,85 & 0,67 & 0,0334 & 0,0236 \\
\hline MAX & 32,50 & 1,97 & 1,62 & 1,22 & 0,77 & 0,72 & 1,10 & 1,04 & 1,13 & 1,06 & 1,27 & 1,17 & 0,0529 & 0,0348 \\
\hline SD & 2,972 & 0,205 & 0,1409 & 0,077 & 0,07 & 0,064 & 0,133 & 0,107 & 0,09 & 0,1 & 0,1 & 0,121 & 0,00469 & 0,00284 \\
\hline
\end{tabular}

Legend: body length (BL), body width (BW), diameter of oral sucker (OSD), diameter of ventral sucker (VSD), width of pharynx (PW), length of pharynx (PL), length of ovary (OL), width of ovary $(\mathrm{OW})$, length of testes $(\mathrm{TL})$, width of testes (TW), length of eggs (EL), width of eggs (EW), average (AV), maximal (MAX) and minimal (MIN) values 


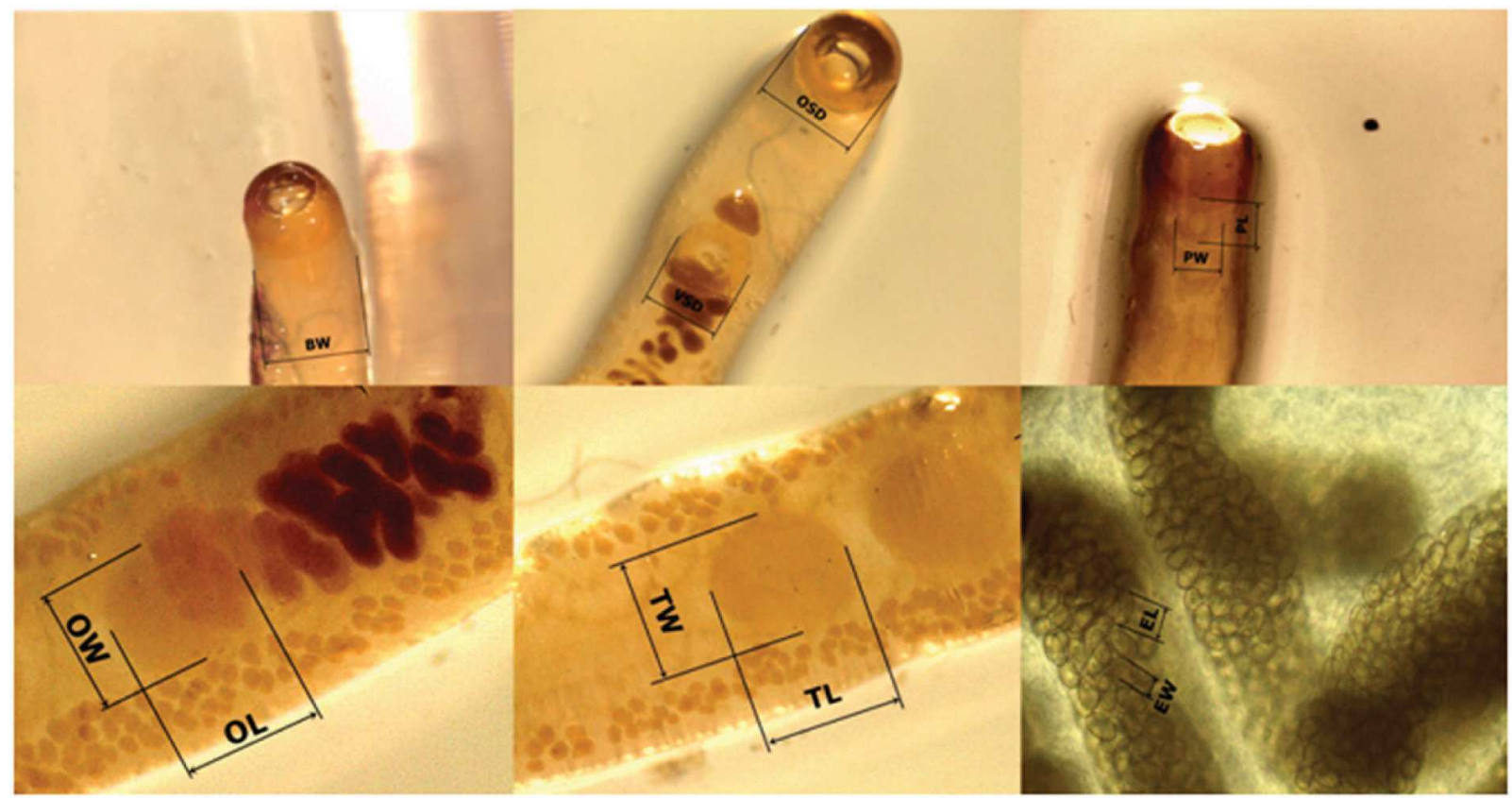

Fig 1. The most important measured body characters of Azygia robusta

Legend: A - mesure of body width; B - measure of diameter of oral and ventral suckers; C - measure of width and length of pharynx; D measure of length and width of ovary; E - measure of length and width of testes; F - mesure of length and width of eggs

is a result of the decreasing number of huchen individuals (Muhamedagic and Habibovic, 2013). Because of its size, attractiveness, habitats and life cycles, this species is under significant negative anthropogenic influence, and in the last 50 years is recorded drop in all populations of its natural range. Three factors are distinguished in their impact on huchen population drop, such as dams, excessive harvesting (all types of poaching) and pollution. The greatest habitat degradation has occurred in Vrbas sub-basins located in central Bosnia and Herzegovina, which is industrial center of former Yugoslavia and the consequences of environmental degradation and industrial pollution are still notable today (Radević, 2000).

Proportion of the huchen Hucho hucho of the ichthyofauna of the river Vrbas, according to Fisheries Management Plan from 1985 , was $22 \%$, while investigations conducted during 1994-1996 show that the proportion of this fish species was $12.49 \%$. This situation can be explained as a consequence of some alterations and pressures on the Vrbas River, as a construction of a dam Bočac and low water flow during summer and fall, water pollution, weak protection measures and mismanagement of fish stocks (Radević, 2000). Because of the new situation, this parasite could adopt on new host from salmonid fishes. Trematod A. robusta is reported for the first time in Vrbas River in huchen specimen (Čanković et al., 1968), while in this study this parasite was found in new fish host, brown trout Salmo trutta.

This new record of $A$. robusta that parasitize on brown trout species could point to a completely new way of adaptation in ecological terms on very rare parasitic host. Considering stated above, parasitology and animal biology have to research this parasite-host relationship and identify consequences on the health of brown trout.

\section{ACKNOWLEDGEMENTS}

This work is supported by Ministry of Education, Science and Technological Development of Republic of Serbia, Projects No. 173045 and No. 173025.

\section{SAŽETAK}

\section{PRVO IZVJEŠĆE O POJAVI Azygia robusta (Odhner, 1911) (Trematoda: Azygiidae) NA POTOČNOJ PASTRVI Salmo trutta U RIJECI VRBAS}

Istraživanja parazita riba u Bosni i Hercegovini postaju značajna zadnjih godina, s toga su novi nalazi o parazitskim trematodama i njihovim domaćinima važni za bolje razumijevanje parazitologije i patologije riba. $U$ ovoj studiji je uzorkovana 41 jedinka parazita i analizirane su značajne morfološke i taksonomske mjere (duljina i širina tijela, promjer usne i trbušne pijavke, duljina i širina ždrijela, duljina i širina jajnika, duljina i širina sjemenika i duljina i širina jaja). Nakon uzorkovanja paraziti su konzervirani u 70\%-tnom 
etanolu te mjereni uz pomoć Digimizer Image Analyzer Version 4.1 računalnog programa. Nakon svih mjerenja, parazit Azygia robusta je potvrđen po prvi puta na potočnoj pastrvi i taj nalaz je pronađen u rijeci Vrbasu kod Banje Luke, Bosna i Hercegovina (sliv rijeke Save). Raniji nalazi ovog parazita u Europi bili na drugim salmonidnim vrstama kao što je mladica, Hucho hucho. Novi nalaz bi mogao biti značajan podatak o parazitologiji riba u Bosni i Hercegovini.

Ključne riječi: paraziti, Bosna i Hercegovina, metilji, novi nalaz

\section{REFERENCES}

Andrić, J. M. (1984): Fish endohelminths in Obedska pound Monography. Science Association, Belgrade. 225.

Bauer, O. N. (1987): Parasitic species of freshwater fish fauna in SSSR. TOM 3. Molecular parasitology. Academy of Science SSSR, Institute of Zoology, Leningrad. 583.

Bykhovskaja-Pavlovskaja, I.E., Gusev, A.V., Dubinina, M.V., Izjumowa, N. A., Smirnova, T.S., Sokolovskaja, I. L., Štein, G. A., Šulman, S. S., Epstein, U. M. (1962): Key to parasites of freshwater fishes of the USSR. House of the USSR Academy of Science in Moscow, Leningrad. 776.

Čanković, M., Delić, S., Kiškarol, M., Rukavina, J. (1968): Parasite fauna of freshwater fish from Bosnia and Hercegovina (Trematoda, Cestoda, Nematoda, Acanthocephala) (in Bosnian). Academy of Sciences and Arts of Bosnia and Hercegovina, Sarajevo. 159.

Djikanovic, V., Paunovic, M., Nikolic, V., Simonovic, P., Ca- kic, P. (2012): Parasitofauna of freshwater fish in Serbian open waters: a checklist of parasites of freshwater fishes in Serbian open waters. Review of Fish Biology and Fisheries, 1, 297-324.

Holčik, J., Hensel, K., Nieslanik, J., Skacel, L. (1998): The Eurasian huchen, Hucho hucho. Largest salmon of the world. Dr. W. Junk Publishers: Dorarecht, Boston, Lancaster. 341.

Kakačeva-Avramova, D. (1983): Helminths of freshwater fish in Bulgaria. Bulgarian Academy of Science, Sofia. 261.

Moravec, F.(2004): Metazoan Parasites of Salmonid Fishes of Europe. Academia, Praha. 511.

Muhamedagic, S., Habibovic, E. (2013): The State and Percpective of Danube Huchen (Hucho hucho) in Bosnia and Herzegovina. Archives of Polish Fisheries; 21: 155-60.

Popiolek, M., Kusznierz, J., Kotusz, J., Witkowsk,i A. (2013): Parasites of Hucho hucho (L.), Hucho taimen (Pall.), and Parahucho perryii (Brevoot) (Salmonidae, Actinopterygii) - the state of knowledge. Archives of Polish Fisheries, 21, 3, 233-9.

Pulgachev, O. N. (2003): Checklist of freshwater fish parasites of the northern Asia. Trematoda. Proceedings of the Zoological Institute: Sankt Petersburg. 218.

Radević, M. (2000): Ecological and cenotic relations of fish fauna in the middle and lower part of the Vrbas river and fishpond Bardaci. Monography. Faculty of Natural Sciences, Banja Luka. 250.

Simonović, P., Nikolić, V., Tošić A. (2011): Fisheries Management Plan for the part of catchment of the Serbia-East fishery area in the 2011-2012 period. University of Belgrade, Faculty of Biology, Belgrade. 61 (in Serbian). 